\title{
Distribution of Achaemenid Period Settlements on the Southwest Iran-Khuzestan Ramhormoz Plain with Survey Data
}

\section{Yüzey Araştırmaları Verileriyle Güneybatı İran-Huzistan Ramhormoz Ovası'nda Akhaimenid Dönem Yerleşimlerinin Dağılımı}

\author{
Leila Afshari ${ }^{1}$ (b)
}

Atatürk Üniversitesi, Sosyal Bilimler Enstitüsü, Arkeoloji Anabilim Dalı, Protohistorya ve Önasya Arkeolojisi Bilim Dalı, Erzurum, Türkiye

\section{ORCID ID: L.A. 0000-0002-7673-6132}

Corresponding author/Sorumlu yazar: Leila Afshari (Barkamaran Tepesi kazı başkanı, Kuzeybatı İran, Piranşehr ilçesi)

Atatürk Üniversitesi, Sosyal Bilimler Enstitüsü, Arkeoloji Anabilim Dalı, Protohistorya ve Önasya Arkeolojisi Bilim Dalı, Erzurum, Türkiye E-mail: le.afshari@gmail.com

Submitted/Başvuru: 29.11.2021

Accepted/Kabul: 17.12.202

Citation/Atıf: Afshari, L. (2021). Distribution of achaemenid period settlements on the Southwest Iran-Khuzestan Ramhormoz plain with survey data. Anadolu AraştırmalarıAnatolian Research, 25, 103-115. https://doi.org/10.26650/anar.2021.1029738

\begin{abstract}
The Ramhormoz region in south and southwest Iran and its large-scale geography extends to the northern highlands of present-day modern Khuzestan. Despite its significance for its connection with the Susa-Persopolis Road during the Achaemenid period, the region did not attract archaeological attention until 1948s. Even in its brevity, the results of the 1969 Wright-Carter survey showed that the Ramhormoz region is promising in shedding light on the relation between the highlands and lowlands of southwest Iran. As a result of new archaeological data and the survey conducted under my supervision, the characteristics of the Achaemenid settlements on the Ramhormoz plain in Southwest Iran were reanalyzed. The influence of geographical factors such as the presence of large rivers and fertile lands on the formation and prosperity of the settlements, and the relations between sedentary, rural, and nomadic communities were examined. It was thus revealed that proximity to commercial roads and access to water resources and pasture were the main determinants in the distribution model of Achaemenid settlements. Rich pastures for nomads, the potential for irrigated agriculture for settlers, and access to communication routes provided advantages for both lifestyles (Alizadeh, 1979). The socio-political control and settlement pattern organized by the central political power in the Late Elamite Period continued in the Achaemenid period as well. Therefore, the settlement pattern is more associated with roads. When the location of the settlements and their distance to each other are examined, it is seen that the frequency of settlements on the Susa-Persepolis Royal Road is very high. Settlements are located on the road within short distances of each other, which shows that the road is a determining factor on settlements in the region due to its socio-economic advantages. During the Achaemenid period, as in the previous period, while settlements continued their development on the slopes of the mountains and on the edge of the plain, they were mainly concentrated in the center of the plain. During this period, the size of the settlements increased, which is indicative of population growth on the Ramhormoz plain during the Achaemenid period.
\end{abstract}

Keywords: Southwest Iran, Khuzestan, Ramhormoz Plain, Achaemenid Period, Mesopotamia, Anatolia 


\section{öz}

İran’ın güney ve güneybatısındaki Ramhormoz bölgesi ve onun geniş ölçekli coğrafyası bugünkü modern Huzistan'nın kuzey dağlık kısmına kadar uzanmaktadır. Bölge 1948 yılına kadar arkeolojik açıdan dikkati çekmemekteydi. Halbuki bu bölge Akhaimenid döneminde Susa-Persepolis yolu üzerinde yer alması oldukça büyük öneme sahiptir. Wright ve Carter'in 1969 yılında gerçekleştirdiği yüzey araştırmaları sonucunda bu bölgenin güneybatı İran'ın ovalık ve dağlık kısımları arasında bağlantının olduğunu göstermektedir. Yeni arkeolojik veriler ve başkanlığımda gerçekleştirilen yüzey araştırmasıyla Ramhormoz ovasındaki Akhaimenid yerleşim karakteri tekrar analiz edilmiştir. Büyük nehirlerin ve verimli tarımsal araziler gibi coğrafi faktörler ile yerleşik, kırsal ve göçebe topluluklar arasındaki ilişkilerin iskana etkisi sorgulanmaya çalışılmıştır. Akhaimenid yerleşimlerinin dağılım modelinde ticari yollara yakınlık, su kaynaklarına ve meraya erişimin belirleyici olduğu tespit edilmiştir. Göçebeler için zengin meralar, yerleşikler için sulu tarım potansiyeli ve iletişim yollarına erişim, her iki yaşam biçimi için de avantaj sağlamıştır. Geç Elam Dönemi'ndeki sosyo-politik kontrol ve yerleşme modeli Akhaimenid döneminde de devam etmiştir. Yerleşim örüntüsü daha çok yollarla ilişkilidir. Yerleşmelerin konumlarını ve birbirilerine göre mesafelerini göz önüne aldığımızda Susa-Persepolis Kral Yolu güzergahındaki yerleşme sıklığının da fazla olduğu ortaya çıkar. Yol üzerinde kısa mesafelerle yerleşmeler konumlanmıştır. Bu da yolun sosyo-ekonomik avantajları nedeniyle bölgedeki iskân anlayışında belirleyici olduğunu gösterir. Akhaimenid döneminde, önceki dönemde olduğu gibi, dağların yamaçlarında ve ova kenarında yerleşmeler devam ederken, ana odağı ovanın merkezindedir. Bu dönemde, yerleşimlerin büyüklüğü artmıştır ve bu da Akhaimenid döneminde Ramhormoz ovasında nüfus artışının göstergesidir.

Anahtar Kelimeler: Güneybatı İran, Huzistan, Ramhormoz Ovası, Akhaimenid Dönem, Mezopotamya, Anadolu 


\section{Introduction}

Our knowledge regarding Achaemenid presence in the south and southwest of Iran is quite limited. The region played an important role in cultural, economic, and political interactions with surrounding geographies such as Mesopotamia and Anatolia throughout the 1st millennium BC (Meadows, 2005). Many uncertainties surround the recognition of cultural characteristics and interactions of the region during the Achaemenid period.

The Ramhormoz plain, the focus of our field study, is situated approximately 120 meters above sea level and covers an area of approximately $620 \mathrm{~km}^{2}$. The Ramhormoz region and its wide geography extend to the northern highlands of present-day modern Khuzestan. It is surrounded by the Masjid Suleiman and Shushtar regions in the north and northwest, Ramshir and Ahvaz in the west and southwest, the Mei Davud region in the east, and the Bagh Malek and Izeh regions in the northeast. Stony, rugged hills surround the region to its north, northeast, and northwest (Alizadeh, Ahmadzadeh \& Omidfar 2014).

Despite its connection with the Susa-Persopolis Road during the Achaemenid period, Ramhormoz did not attract archaeological attention until the late 1948s. Even in its brevity, the results of the 1969 Wright-Carter survey showed that the Ramhormoz region is promising in shedding light on the relation between the highlands and lowlands of southwest Iran.

The significance of the region was further revealed with the surface surveys carried out by Donald Mc Cown in the region and the excavations he conducted at Telle Geser (McCown, 1949, 1954). Surveys conducted by Wright and Carter in 1969 also pointed to connections between the region's lowland and mountainous parts of southwestern Iran (Wright and Carter, 2003). Although the dimensions are different, it has been observed that the settlements share some common features with the mountainous parts of Persian geography. As a result of contemporary archaeological resources and the survey conducted under my supervision, the characteristics of the Achaemenid settlements in the Ramhormoz plain in Southwest Iran were reanalyzed. The influence of geographical factors such as the presence of large rivers and fertile lands on the formation and prosperity of the settlements and the relations between sedentary, rural, and nomadic communities were studied. Also, the transformations in the settlement system, distribution, and population differences during the Achaemenid period were revealed and subsequently / mapped (Figure 1).

\section{Analysis of Achaemenid Settlements}

In this study, various variables related to the distribution model of the Achaemenid settlements were examined using environmental analyses and Arc GIS software, in line with the purpose of the study and how the settlements of the Ramhormoz plain were formed and continued. It has been determined that the most important factors were proximity to commercial roads and 
access to water resources and pasture. Settling in areas with rich pasture cover for nomads in the region, living in a place with irrigated agriculture potential for agriculture and rural communities, and access to communication routes was advantageous for both lifestyles. The socio-political control and settlement pattern organized by the central political power in the Late Elamite Period continued in the Achaemenid period as well. Therefore, the layout pattern is more associated with roads. The need to be near the main rivers was not felt. In the Achaemenid period, as in the previous period, while settlements continued developing on the slopes of the mountains and the edges of plains, they were mainly concentrated in the center of the plain (Figure 2). During this period, the size of settlements increased, which is considered evidence of population growth in the Ramhormoz plain during the Achaemenid period. Signs of interaction between this region and the cultural areas of southwestern Iran, southern Mesopotamia, and eastern Anatolia are evident in the archaeological data and through the shape and decoration of pottery. Below, the settlement pattern of the Ramhormoz plain in the Achaemenid period has been analyzed using ArcGIS. The distance of the settlements to roads, their location to water resources, their position above sea level, the use of the land, location according to the vegetation in the region, and the distance and location of settlements from each other are among the variables.

The Ramhormoz plain is strategically located on the important passageways from Khuzestan to Persepolis and the western regions of the Achaemenid Empire, such as Mesopotamia and Anatolia. As a result of the archaeological studies carried out on the section of the Royal Road from Susa to Persepolis, remains of buildings purposed to serve travelers were found (Egtedari, 1996). The Susa-Persepolis Royal Road was an important communication route between the plain of Ramhormoz, Persepolis, Susa, and the western parts of the empire (Yagmaei, 2016). In fact, the Ramhormoz plain, with its wide area and natural roads, had the potential to provide communication opportunities within the region and later with other geographies (Imanpour, 2010).

Water resources have always played a definitive role in the formation of settlements. Settlements established along permanent or seasonal rivers show the settlement pattern and distribution of the region. The Ramhormoz plain has extensive underground water resources as well as numerous surface water resources such as rivers and springs (Figure 3 ). The focal point of the settlement model, which dominated the distribution of areas in the Ramhormoz plain from prehistoric times to the end of the Islamic period, was easy access to water from the springs and rivers flowing from this plain. The fertile soils and rich pastures in this region met the needs of the hybrid economy of the communities (Alizadeh, Ahmadzadeh \& Omidfar 2014). Moreover, the strategic roads passing through the region also enabled the formation of trade-oriented settlements.

There is a close relationship between precipitation, the characteristics of flora and fauna, and the elevation of settlements, which consequently affects the lifestyle of these communities 
(Figure 4). In Ramhormoz plain, it is seen that most of the settlements were formed in the low central part of the plain in the Achaemenid period to utilize arable land and access main roads. In addition, a few settlements were formed in the northern and southern parts of the plain and the high-altitude areas, as this provided favorable conditions for animal husbandry, horticulture, and possibly agricultural life. There are also settlements which were established on higher elevations, especially to protect trade routes and to provide logistics for travelers.

The research area of this study has agricultural potential due to its abundant access to water resources, rich pasture resources, and arable land in some places. Regarding the land use variable, it can be said that the settlement occurred in two dominant patterns, one in the plain and irrigated lands, and the other in higher altitude areas with rich pasture cover for livestock. This shows that settlement policy within the Achaemenid period not only focussed on animal husbandry and rural agriculture, which were the dominant traditional lifestyles of the region, but it also grew and expanded through organized agriculture and irrigation.

All of the Achaemenid settlements on the Ramhormoz plain are interrelated. It was revealed that there were micro settlements that facilitated interaction between them (Figure 5-6). This settlement distribution allowed them to establish stronger communication. Analogical evaluation of the pottery from the plain settlements brings us to this conclusion. Again, the distribution of the settlements located on the highlands shows that they were inhabited in connection with rivers and ancient roads.

The landscape is the sum of all that surrounds us wherever we are. It emerges as a product of natural elements such as mountains, hills, plains, valleys, water surfaces, rivers, vegetation, and human intervention in these elements (Tuna, 2015).

As mentioned before, the settlements on the Ramhormoz Plain are within proximity to natural resources and commercial roads. This situation paved the way for the formation of important cultural interactions on the plain.

Another important factor in the analysis of settlements is their size. This indicator allows us to roughly predict the importance of the region and its population at different times. However, it is often difficult to determine the periodic spread of a settlement solely from the surface findings. The topography of the hill does not show the periodic size of the settlement. Walled areas, on the other hand, provide us with relatively solid grounds for evaluation. When we set aside these concerns and evaluate the settlement policy in the Ramhormoz Plain, we see the settlement distribution and sizes corresponding to three geographical sections. The sections close to the Zagros Mountains in the north are smaller in size and are sparsely distributed. To the south of this section, larger settlements emerge. These settlements are of medium size and feature a denser settlement character. While the large settlements in the 
center of the plain are the center of attraction for both areas, it is understood from the pottery finds that the small and medium-sized settlements in the northern and southern regions also established a dense communication network among themselves (Figure 6-8).

It has been determined that most of the settlement areas in the Ramhormoz plain were located in the center of the plain (Figure 8). In light of this data and considering the settlement distribution in the Late Elam period, it can be said that the number of settlements increased, and their size grew during the Achaemenid period. In general, settlements with more independent areas and more connections were in the southern part of the plain. The northern part is closer to water sources and has higher elevations. It can be said that the settlement in this area was generally shaped according to the natural and geographical conditions of the Zagros region. Smaller and sparse settlements are a result of the region's topographic conditions.

The above-mentioned data reveal a fertile plain in the pre-Achaemenid period. However, it is possible to say that the settlement behavior showed a more controlled development with Darius as a result of the expansion of the road system and the creation of trade and financial units. In fact, all of this is the result of the need to establish an effective cultural and commercial relationship between the satraps in the different regions of the Achaemenid Empire.

\section{Conclusion}

The southwestern region of Iran played an important role in establishing cultural, economic, and political interactions with surrounding areas such as Mesopotamia and Anatolia throughout the 1st millennium BC. The number of archaeological studies conducted in the Ramhormoz area has been quite limited. Despite the lack of archaeological information, the studies carried out in recent years have shown the significant role the cultures in the region (both the mountain and plain settlers) played in understanding the Achaemenid Culture. The location of the region, the nature of the settlements between the plains and the mountains, their cultural communication with each other, and their continuity also provide a model for us to understand the settlement policy of the Achaemenid World (Meadows, 2005). In addition, its location is of great importance in terms of the relations between Iran and Anatolia during the Achaemenid period (Summers, 1993; Bocchieriyan, 2016).

Ramhormoz plain is of great significance due to its being on the Susa-Persepolis royal road during the Achaemenid period. A total of 16 sites related to the Achaemenid period had been mentioned before the archaeological study carried out under the direction of the author in the plain of Ramhormoz.

However, when we considered factors such as favorable climate and soil for agriculture, the existence of major rivers such as Kupal and Sandali, proximity to trade routes such as the Susa-Persepolis royal road, and to two important capitals of the Achaemenid period, Susa and 
Persepolis, we expected a much higher number of Achaemenid settlements than the stated figure. During our research, the areas identified by the previous team were reviewed and many new areas related to the Achaemenid period were identified. As a result, the number of Achaemenid settlements in the Ramhormoz plain increased from 16 to 36 . This conclusion is vital to the archeology of the Achaemenid period and will affect many theories. Before this study, it was stated by the previous team that the hectares of settlements belonging to the Achaemenid period were scarce in this plain and it was a place that could have been used by seasonal nomads (Alizadeh, Ahmadzadeh \& Omidfar 2016). Undoubtedly, after Assurbanipal's attack on Susa, these areas suffered great damage and security concerns increased. However, with the arrival of the Achaemenids, the security of these areas must have been restored and the previous settlements began to be used again (Negahban, 2011).

The distribution of pottery detected during our study has provided us with crucial data on the settlement character and settlement policy. First of all, the settlements are located near or connected with the Susa-Persepolis trade route. The rich geographical conditions of the plain have affected the settlement dynamics over time. Despite the intense destruction of modern settlements and industrial agricultural activities, the settlement areas identified show direct or indirect relations of many settlements with commercial or military means during the Achaemenid period. In other words, the main dynamic in the formation of these settlements along the trade routes is the ease of intra-regional and extra-regional communication. The proximity of the settlements to the Susa-Persepolis royal road indicates that they played an important role in the interaction of the Achaemenid cultures. The archaeological studies conducted under the leadership of İsmail Yaghmaei were important in determining the settlement remains on the Susa-Persepolis royal road, which revealed the characteristics of this settlement policy (Saidian, 2019). At this point, we can talk about the settlements on the Susa-Persepolis Road and the Kout Castle, where remains of buildings that most likely served travelers were discovered.

The fact that the Kout castle is located within the borders of the Ramhormoz plain shows that the settlements belonging to the Achaemenid period in this plain had important cultural and economic communications within and outside the region. Tell-e Ishan Seyed Shabib or Tell-e Toppi, Tepe Mava, Tepe Mehr AlNesa, and Tepe Kheyr Al Nesa are amongst the examples of similar settlements of this type. When we consider the locations of the settlements and their distance from each other, we see that the settlement frequency on the Royal Road route is rather high. Settlements are located on the road within very short distances of each other. This shows that the road is decisive in the formation of settlements in the region and that the economic and political advantages of the road are quite high. As Koch (Koch, 2001) emphasized, these settlements provided economic relations with caravans passing through the royal road. This enabled the plain to progress in terms of economy and prosper. In other words, the most important factor that brought the Ramhormoz plain into the spotlight during the Achaemenid period was its location on the Susa-Persepolis Royal Road (Graf, 1994). 
Pottery reveals to us the technology of the period, the settlement it was produced at, the taste or fashion of its era, interactions between commercial relations and surrounding cultures, and what kind of food was consumed. These data have proved to be very helpful in determining the settlement understanding of the region. The pottery we obtained from each settlement belonging to the Achaemenid period on the Ramhormoz plain is related to daily use and storage. All known forms of the ceramic repertoire of the Achaemenid period were observed in the materials we examined. We see types of ceramics made on a fast-rotating wheel, some of which are made by hand and in some forms with hand and wheel. Bowls and cups, which are considered together with their subtypes, constitute an important part of the vessels. Plates, short and long-necked jugs, and storage jars are among the forms seen.

The ware groups evaluated in the Ramhormoz plain belong to the light green slipped ware group, representing the highest percentage in all river regions. The red slip and unslipped plain ware group constitute the majority of the remaining ceramics. Monochrome painted wares with decoration, unslipped and light green slip are less numerous among the material we found in the settlements of the Ramhormoz plain. It has been observed that the clay is generally of medium thickness or thin. All of the pottery examined had been fired at high temperatures. When evaluated in terms of production technology the ceramics obtained from the Ramhormoz plain were classified according to their mouth, neck, and body widths. In this framework, the vessels consist of shallow bowls, bowls, cups, neckless pots, short-necked pots, long-necked pots, jugs, and storage jars. In these forms, simpler and plainer vessels are more commonly featured compared to complex types.

Almost all the settlements on the Ramhormoz plain are located on the banks of 6 important rivers, and according to the pottery we obtained, it is understood that they had strong communication with each other, as well as with neighboring regions. It can be said that there was a local and highly developed ceramic industry on the plain during the Achaemenid period. In addition, when we evaluated the structural properties of the clay used, it was understood that there were imported ceramics as well.

When we examine the vessel forms, examples from the early, middle, and late Achaemenid periods are encountered. The characteristic Achaemenid pottery in the region shows that the cultural structure continued without interruption from 550 to $330 \mathrm{BC}$.

Peer-review: Externally peer-reviewed.

Conflict of Interest: The author has no conflict of interest to declare.

Grant Support: The author declared that this study has received no financial support. 


\section{References}

Alizadeh, A. (1979). Baztab-e Nagsh-e Jografiyayi, Zistmohiti va Egtesadi dar Tahavolat-e Jonoub-e Bakhtari Iran (Az Pish az Tarikh ta Eslam), Majale Asar 21, 29-42.

Alizadeh, A. \& Ahmadzadeh, L. and Omidfar M. (2014). Ancient Settlement Patterns and Cultures in the Ram Hormuz Plain, Southwestern Iran: Excavations at Tall-e Geser and Reginal Survey in the Ram Hormuz Area, Chicago: Oriental Institute Publications 140.

Alizadeh, A., Ahmadzadeh, L. \& Omidfar, M. (2016). Sistemhaye Estegrari va Farhanghaye Bastani Dashte Ramhormoz Jonoub Garbi Iran (Natayej Kavosh dar Tell Geser va Barresi Mantageyi Ramhormoz).

Bocchieriyan, S. (2016). The Achaemenid Satrapy of Armenia. Colorado: University of Colorado.

Egtedari, A. (1996). Khuzestan va Kogilouyeh va Mamesani-Jografyaye Tarikhi va Asar Bastani, Jeld 3 dar Majmoe Asar Khuzestan, Anjoman Asar va Mafakher Farhangi.

Graf, D. F. (1994). The Persian Royal Road System. in: Sancisi-Weerdenburg, H. \& Kuhrt, A. and Root, M. C. (Eds.). Achaemenid History VIII: Continuity and Change, Leiden, Nederland Instituut Foor Het Nabije Oosten, pp.167-189.

Imanpour, M. T. (2010). The Communication Roads in Parsa during the Achaemenid Period. İn Macuch, M \& Weber, D. and Meisterernst D. (Eds), Ancient and Middle Iranian Studies, Proceedings of the $6^{\text {th }}$ European Conference of Iranian Studies, Held in Vienna, 18-22 September 2007, pp.87-99.

Koch, H. (2001). Az Zabane Darius, (Çev. Parviz Rajabi), Entesharat Karang, Tehran.

McCown, D. E. (1949). The Iranian project, American Journal of Archaeology, Vol. 53/1:54.

McCown D. E. (1954). The Relative Stratigraphy and Chronology of Iran. In Relative Chronologies in Old World Archaeology, Robert W.Ehrich (Edt), Chicago University of Chicago Press, 56-67.

Meadows, A. R. (2005). The Administration of the Achaemenid Empire, in John Curtis, \& Nigel Tallis (Ed.), Forgotten Persian Empire: The World of Ancient Persia. London: British Museum, pp.181-210.

Saidian, S. (2019). Gozaresh-e Barresi va Shenasayi Bastan Shenasi Mahdoudeh Projeye tosea va Bahrebardari az Roudkhaneh Aras dar Azarbayjan garbai (Sad-e Karam Abad Poldasht). Gozareshte Barresi, Arşiv-e Pazhoheshkade Bastan shenasi.

Summers, G.D. (1993). Archaeological Evidence for the Achaemenid Period in Eastern Turkey. Anatolian Studies 43, 85-108.

Tuna, A. (2015). Arkeolojik Sitelerde Peyzaj Tasarımı, I. Ulusal Ankara Üniversitesi Peyzaj Mimarlığı Kongresi, 15-17 Ekim, 173-181.

Wright, H. T. \& Carter E. (2003). Archaeological Survey on the Western Ram Hormuz Plain, 1969. İn Naomi F. Miller \& Kamyar A. (Eds) Yeki Bud, Yeki Nabud: Essays on the Archaeology of Iran in Honor of William M. Sumner. Los Angeles Cotsen Institute of Archaeology Monograph 48, University of California Press, pp. 61-82.

Yagmaei, E. (2016). Gozaresh-e Asib Shenasi Barkhi az Mohavatehaye Motalea Shode dar Barname Shenasayi Rah-e Shahi Hakhamaneshi Shush-Takhte Jamshid. Fasl-e Dovom, Zemestan, Pazhoheshgah Miras Farhangi va Gardeshgari. 


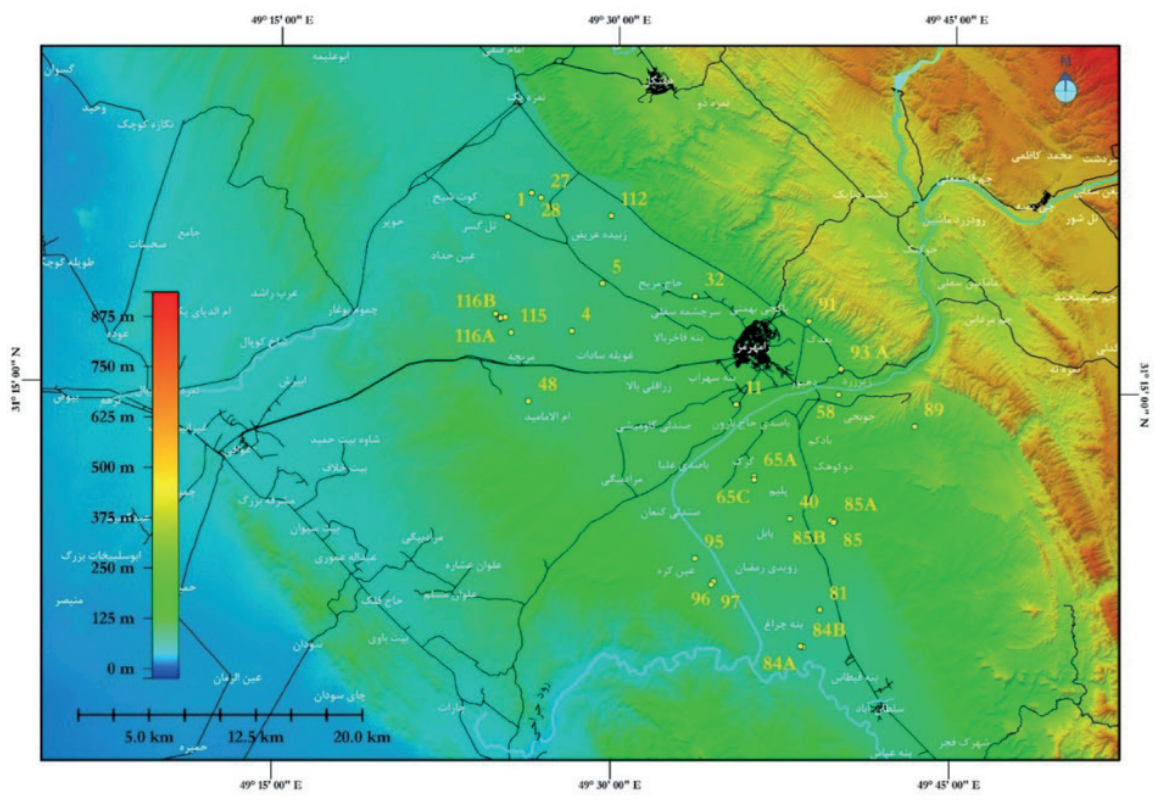

Figure 1. Distribution of Achaemenid Settlement in the Plain of Ramhormoz:1. Tall-e Geser; 4. Tall-e Gavileh; 5. Tape Ishan Gazou; 11. Tall-e Bormi; 27. Tape Ariz Ahmadi; 28. Tape Cham Reji/Cham Hendevane; 32. Tall-e Abbas; 40. Tape Mava; 48. Tape Garavol; 58. Jobaji; 65 A. Tape Mehr Alnesa; 65 C. Tape Kheyr Alnesa; 77 C. Tall-e Gapu Cham; 81. Tape Ishan Embrij; 84 A. Tall-e Gobeyr; 84 B. Tall-e Gobeyr ; 85. Tall-e Rigi(Tall-e Suz); 85A. Tall-e Rigi; 85B. Tall-e Rigi; 89. Ab Mahak; 91. Pache Kouh; 93A. Tall-e Gour Piyazi; 95. Eyn Kore; 96. Tape Boleibol; 97. Tape Dimeh Sadat; 115. Tall-e Mentar; 116 A. Tall-e Kaviri; 116B. Tall-e Karami

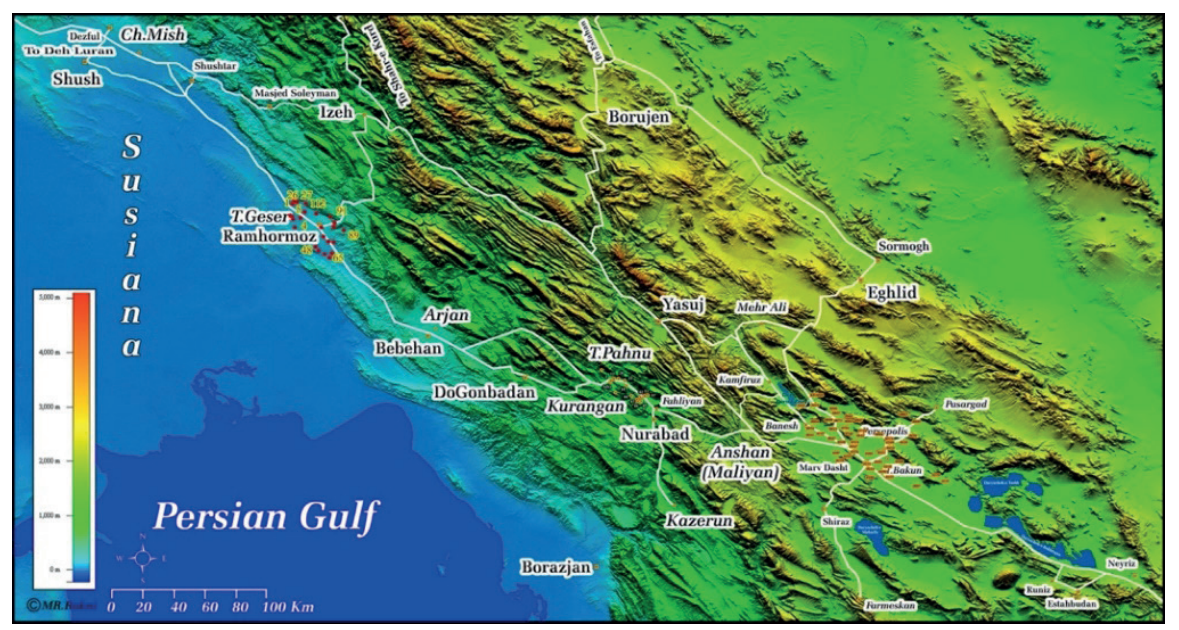

Figure 2. Distance of settlements by roads 


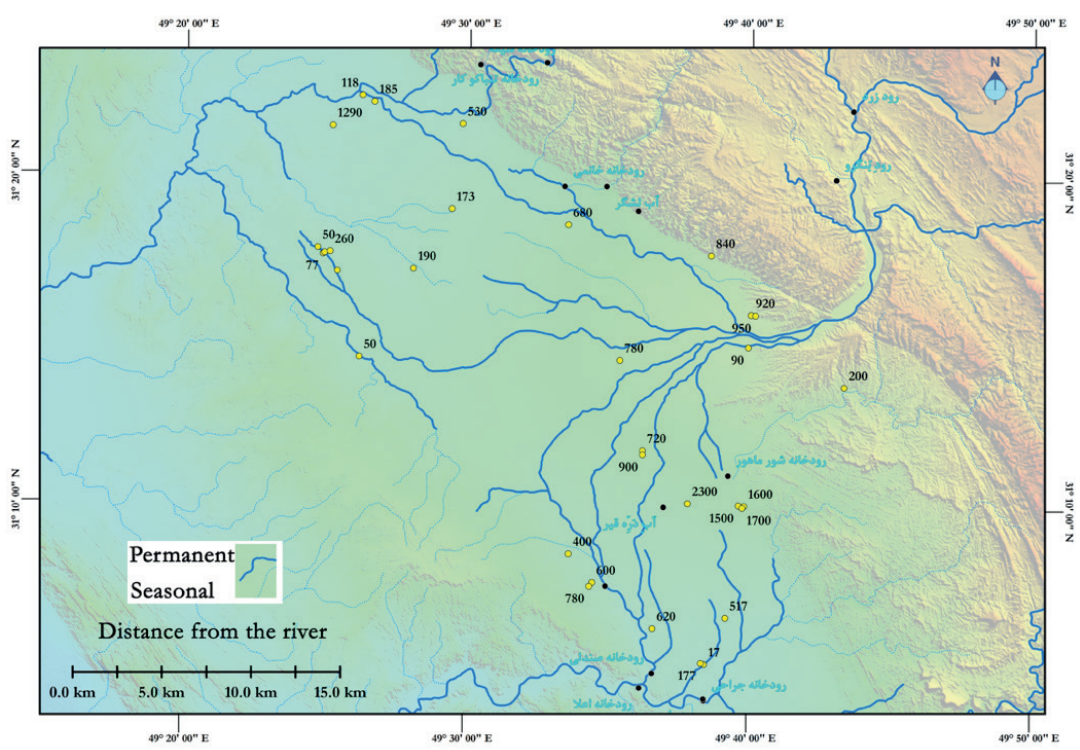

Figure 3. Location of settlements by water resources

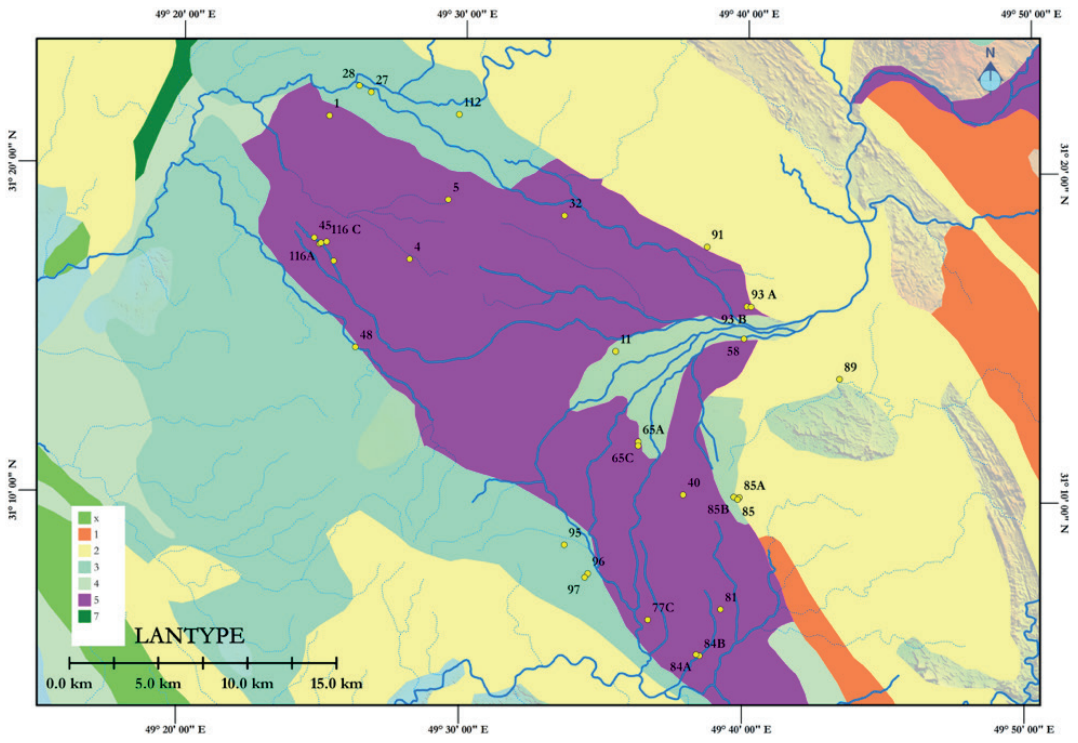

Figure 4. Distance of settlements by lands 


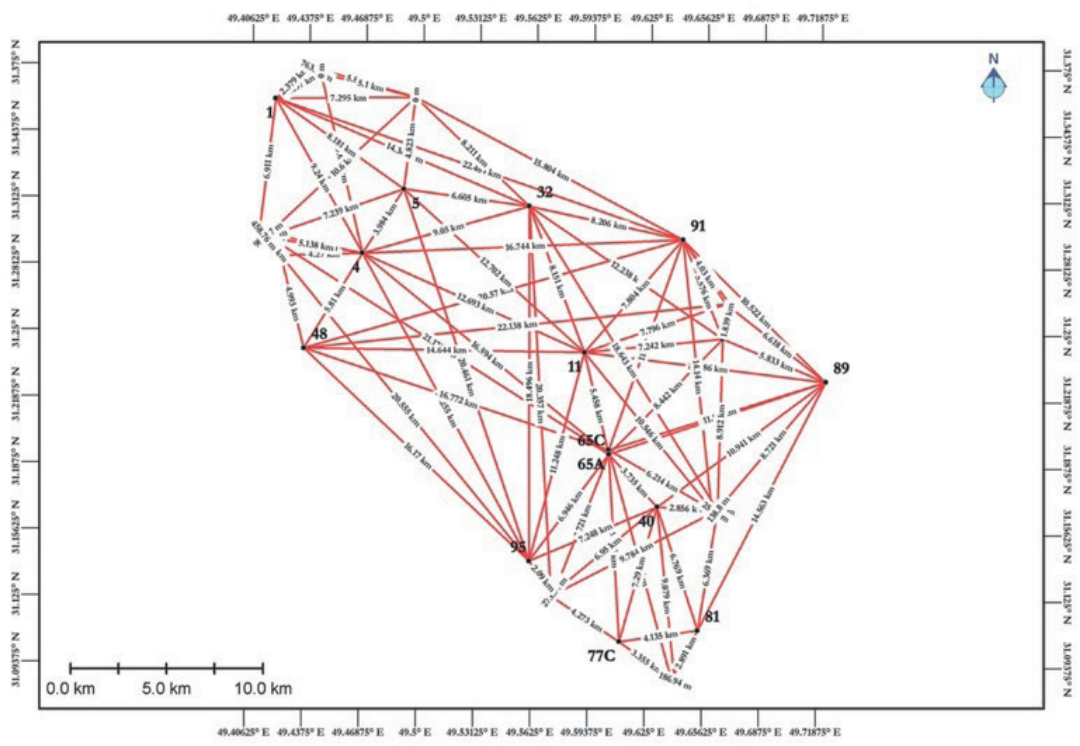

Figure 5. Distance of settlements by roads

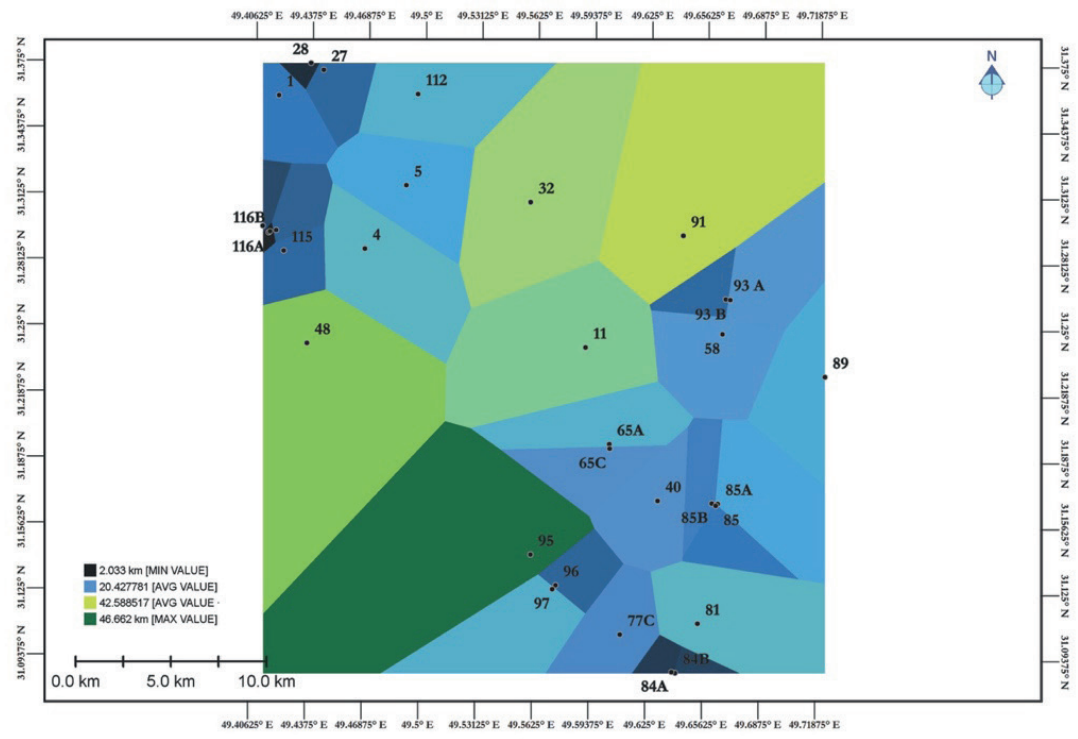

Figure 6. Distance of settlements to each other 


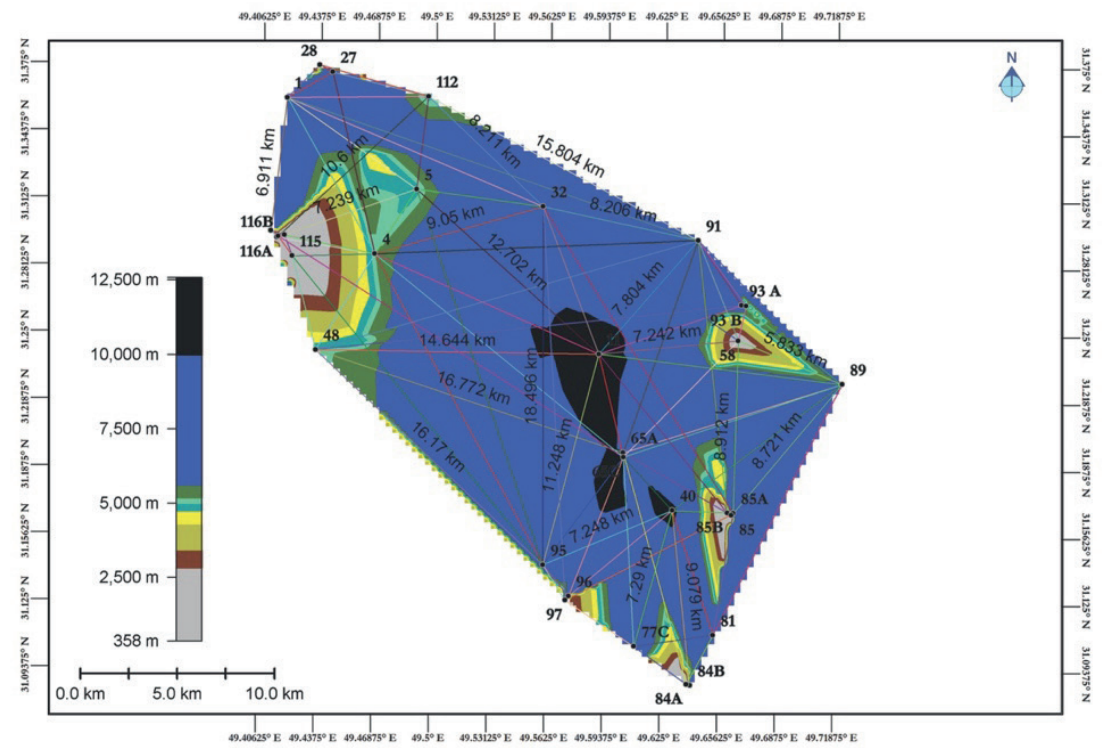

Figure 7 . The Distance of the settlements by roads and the centrally located settlements

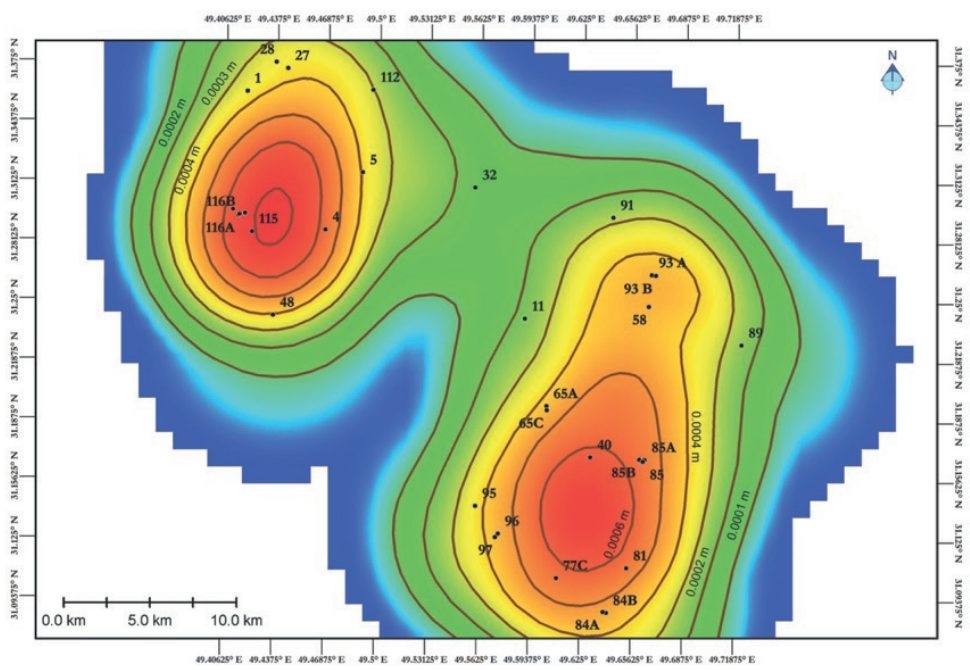

Figure 8. Cultural and commercial relations of the settlements 
